\title{
New Therapeutic Approach for Impaired Arteriogenesis in Diabetic Mouse Hindlimb Ischemia
}

\author{
Shyamal Chandra Bir, MBBS; Masatoshi Fujita, MD*; Akira Marui, MD; Keiichi Hirose, MD; \\ Yoshio Arai, MD; Hisashi Sakaguchi, MD; Yuhong Huang, MD; Jiro Esaki, MD; \\ Tadashi Ikeda, MD; Yasuhiko Tabata, PhD**; Masashi Komeda, MD
}

\begin{abstract}
Background The combined treatment of sustained-release basic fibroblast growth factor (Sr-bFGF) and a 5hydroxytryptamine2A blocker, sarpogrelate, was evaluated to see whether it reversed the impaired collateral circulation in diabetic (DM) mouse hindlimb ischemia.

Method and Results Diabetic and normal mice with ischemic hindlimb were randomly assigned to 1 of 5 experimental groups (no treatment, sarpogrelate $50 \mathrm{mg} \cdot \mathrm{kg}^{-1} \cdot \mathrm{day}^{-1}, 20 \mu \mathrm{g}$ or $50 \mathrm{\mu} \mathrm{Sr}-\mathrm{bFGF}$ and a combined treatment of $20 \mu \mathrm{g} \mathrm{Sr}$-bFGF and sarpogrelate), and treated for 4 weeks. Tissue blood perfusion (TBP), vascular density (angiogenesis) and the number of mature vessels (arteriogenesis) were checked by the use of standard methods. Although angiogenesis was comparable $\left(161 \pm 14\right.$ vs $154 \pm 12$ vessels $\left./ \mathrm{mm}^{2}\right)$, the laser Doppler perfusion image index (LDPII) $(0.43 \pm 0.11$ (SD) vs $0.63 \pm 0.08, \mathrm{p}<0.05)$ and arteriogenesis $\left(8 \pm 3\right.$ vs $12 \pm 4$ vessels $/ \mathrm{mm}^{2}$, $\mathrm{p}<$ 0.05 ) were significantly lower in DM mice than those in normal mice. The dose of Sr-bFGF for the sufficient number of mature vessels ( $\geq 45$ vessels $/ \mathrm{mm}^{2}$ ) and LDPII $(\geq 0.9)$ was $20 \mu \mathrm{g}$ for the normal mice, and $50 \mu \mathrm{g}$ for the DM mice, which was reduced with the aid of sarpogrelate.

Conclusions A combined therapy of Sr-bFGF and sarpogrelate is effective for neovascularization to reverse the impaired arteriogenesis and TBP in DM mice. (Circ J 2008; 72: 633-640)
\end{abstract}

Key Words: Diabetic mouse; Growth factors; Hindlimb ischemia; Neovascularization; Serotonin blocker

$\mathbf{P}$ eripheral arterial disease (PAD) is one of the critical problems in the cardiovascular field and the prevalence of this disease is now increasing along with the recent rise in the proportion of a geriatric population around the world. Furthermore, PAD with diabetes mellitus $(\mathrm{DM})$ is a major concern as PAD patients with DM have less favorable outcomes compared with those without DM, including a 3 - to 4 -fold increase in mortality!-4

Therapeutic angiogenesis with growth factors constitutes a potential alternative approach for the patients with PAD to improve perfusion of ischemic tissues, 5 The establishment of a stable and functional blood vessel network, however, is a complex process that requires several angiogenic factors aimed at stimulating vessel sprouting and remodeling of the pre-existent collateral network ${ }^{-9}$ There is strong evidence that endothelial-dependent vasodilatation and collateral development are impaired in DM ${ }^{10-13}$ Among growth factors, basic fibroblast growth factor (bFGF) is a potent mitogen for growth of both endothelial and vascular smooth muscle cells $, 4,15$ and it can also develop functional collaterals in the rabbit ischemic hindlimb model ${ }^{16}$ Howev-

(Received April 26, 2007; revised manuscript received October 15, 2007; accepted November 21, 2007)

Department of Cardiovascular Surgery, *Human Health Sciences, Kyoto University Graduate School of Medicine and **Department of Biomaterials, Institute for Frontier Medical Sciences, Kyoto University, Kyoto, Japan

Mailing address: Masashi Komeda, MD, Department of Cardiovascular Surgery, Kyoto University Graduate School of Medicine, 54 Kawahara-cho, Shogoin, Sakyo-ku, Kyoto 606-8507, Japan. E-mail: komelab@kuhp.kyoto-u.ac.jp

All rights are reserved to the Japanese Circulation Society. For permissions, please e-mail: cj@j-circ.or.jp er, whether bFGF treatment is effective for the treatment of hindlimb ischemia with DM is not yet established. As bFGF is rapidly degraded in plasma, it is obvious that its delivery system, which is used in therapy, is one of the most important factors to achieve a significant collateral circulation. To overcome this problem, we have developed a sustained-release bFGF incorporated in gelatin hydrogel microspheres for use in various animal models against cardiovascular disease ${ }^{17,18}$

The plasma level of 5-hydroxytryptamine (5HT) in patients with DM is elevated ${ }^{19}$ As a result, dilation of collaterals could be compromised by excessive vesoconstrictive reactivity to $5 \mathrm{HT}$, mediated by $5 \mathrm{HT} 2 \mathrm{~A}$ receptors ${ }^{20}$ In contrast, sarpogrelate (a selective 5HT2A blocker) suppresses blood vessel constriction and can improve distal perfusion in an animal model of hindlimb ischemia, ${ }^{21,22}$ and it is also used for patients with chronic PAD?3

The purpose of the present study was to evaluate: (1) the expression of 5 $\mathrm{HT}_{2} \mathrm{~A}$ receptors and the intrinsic pattern of neovascularization in ischemic hindlimb of streptozotocin (STZ) induced DM mice; and (2) the treatment effect of sustained-release bFGF or sarpogrelate alone, or in combination.

\section{Methods}

\section{Experimental Animals}

Six-week-old male C57BL/6 mice were purchased from Japan SLC (Shizuoka, Japan). The Kyoto University Animal Experiment Committee approved the experiment protocol. Animals were cared for in compliance with the Guide for the Care and Use of Laboratory Animals, Institute of Laboratory Animal Resources, Commission on Life Sciences, National 
Table 1 Primer Sequences Used for Real Time-PCR Receptors Expression

\begin{tabular}{cc}
\hline \hline Primer & \multicolumn{1}{c}{ Sequence } \\
\hline 5HT2A receptors & \\
Forward primer & TAGCCGCTTCAACTCCAGAACC \\
Reverse primer & AAGACCTTCGAATCATCCTGTAGCC \\
GAPDH & \\
Forward primer & AAATGGTGAAGGTCGGTGTG \\
Reverse primer & TGAAGGGGTCGTTGATGG
\end{tabular}

5HT, 5-hydroxytryptamine; GAPDH, glyceraldehyde-3-phosphate dehydrogenase.

Research Council. To generate a diabetic model, 6-week-old male C57BL/6 mice were randomized to receive an intraperitoneal injection of STZ $\left(150 \mathrm{mg} \cdot \mathrm{kg}^{-1} \cdot \mathrm{dose}^{-1}\right)$ dissolved in $1 \mathrm{~mol} / \mathrm{L}$ sodium citrate buffer, $\mathrm{pH} 4.5$ or vehicle. Two weeks after receiving the injection, the serum glucose level was measured by using an Accuchek II Advantage Glucometer (Roche Diagnostics, Bazel, Switzerland). The mice with a serum glucose level less than $200 \mathrm{mg} / \mathrm{dl}$ received an additional half-dose of STZ and finally mice with a serum glucose level less than $200 \mathrm{mg} / \mathrm{dl}$ were excluded from the study?

\section{Mouse Ischemic Hindlimb Model With Various Treatment Profiles}

Hindlimb ischemia was created in the 8-week-old male wild-type and DM mice. Briefly, after the mice were anesthetized by an intraperitoneal sodium pentobarbital $(60 \mathrm{mg} / \mathrm{kg})$ injection, the right groin area was shaved and prepared with povidone-iodine. The entire right saphenous artery and vein, right external iliac artery and vein, and deep femoral and circumflex arteries and veins were ligated, cut, and excised to obtain a mouse model of severe hindlimb ischemia as described previously!

After surgery, the mice with hindlimb ischemia were randomly assigned to 1 of 5 experimental groups and treated for 4 weeks: group N, no treatment; group S, treated with a supplemented diet containing sarpogrelate $\left(50 \mathrm{mg} \cdot \mathrm{kg}^{-1}\right.$. day $\left.{ }^{-1}\right)$; group F20, single intramuscular injection of a sustainedrelease form of bFGF microspheres $(20 \mu \mathrm{g})$; group F50, single intramuscular injection of a sustained-release form of bFGF microspheres $(50 \mu \mathrm{g})$; group F20+S, combined treatment of a sustained-release bFGF $(20 \mu \mathrm{g})$ and sarpogrelate.

An intraperitoneal injection of pentobarbital $(60 \mathrm{mg} / \mathrm{kg})$, subjected to the measurements described below, was provided and then the mice were killed with an overdose of pentobarbital so that a histological examination could take place.

\section{Expression and Quantification of the 5HT2A Receptor by Real Time (RT)-PCR}

For the RT-PCR analysis, wild-type and DM mice were treated as mentioned above and killed on days 3 and 7 after the induction of ischemia.

The ischemic (right thigh muscles) and the non-ischemic (left thigh muscles) tissues were excised and snap-frozen in liquid nitrogen. Total muscle RNA was extracted by using an RNeasy ${ }^{\circledR}$ fibrous tissue mini RNA isolation kit (Qiagen, Mainz, Germany), according to the manufacturer's recommendations. Briefly, total RNA was eluted from the RNeasy ${ }^{\circledR}$ mini columns with $30 \mu 1$ of RNAse-free water and centrifugation with $10,000 \mathrm{rpm}$ for $1 \mathrm{~min}$. Quantitative RT-PCR was performed by using a QuantiTect ${ }^{\circledR}$ SYBR Green RTPCR kit (Qiagen) in a 50 1 reaction volume. The final reac-

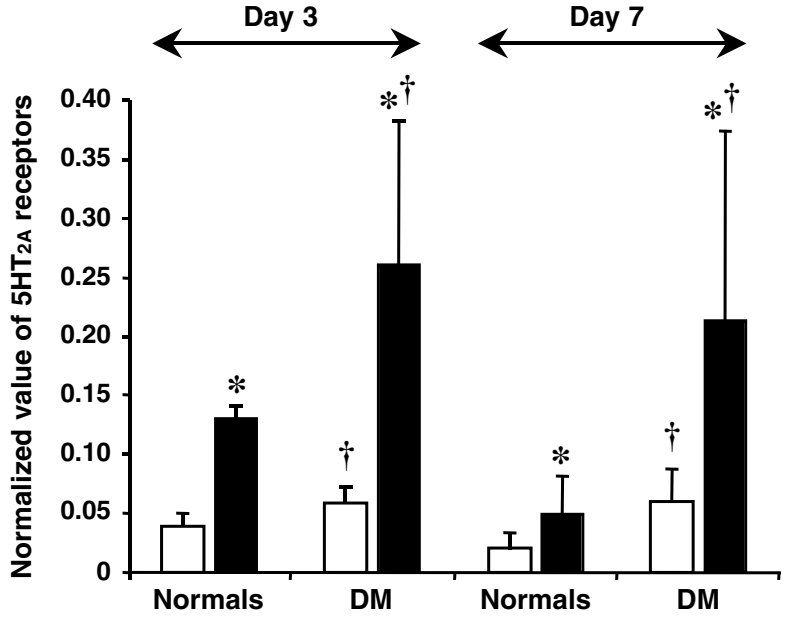

Fig 1. Expression of 5-hydroxytryptamine (5HT)2A receptors in nonischemic (open bars) and ischemic (closed bars) tissues of the thigh muscle in normal and diatetic (DM) mice on days 3 and 7 after the induction of hindlimb ischemia. ${ }^{*} \mathrm{p}<0.05$ vs non-ischemic tissue; ${ }^{\dagger} \mathrm{p}<0.05$ vs normals.

tion contained a 1x QuantiTect ${ }^{\circledR}$ SYBR Green RT-PCR

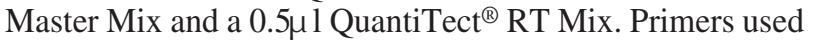
for the PCR are listed in Table 1. The final concentration of the forward and reverse primer was $500 \mathrm{nmol}$. The thermal cycle parameters for reverse transcription and amplification were as follows: $50^{\circ} \mathrm{C}, 30 \mathrm{~min}$ (Hold); again $95^{\circ} \mathrm{C}, 15 \mathrm{~min}$ (Hold); $94^{\circ} \mathrm{C}, 15 \mathrm{~s}$ (Melt); $60^{\circ} \mathrm{C}, 30 \mathrm{~s}$ (Anneal); $72^{\circ} \mathrm{C}, 1 \mathrm{~min}$ (Extend); 40 cycles for each. Compensation between the PCR plate wells was conducted by using the Well Factor Plate Method using a Well Factor Solution (Bio-Rad, Hercules, CA, USA), according to the $\mathrm{iCycler} \mathrm{iQ}^{\circledR}$ manual. The mRNA value was measured with the threshold of 3,700 for 5 HT2A receptors and 1,130 for glyceraldehyde-3phosphate dehydrogenase (GAPDH) by using the iCycler $\mathrm{iQ}^{\circledR}$ (Bio-Rad) Real-Time PCR Detection System, Software Version 3.0A. A standard curve was depicted by plotting the mean $\mathrm{C}_{\mathrm{T}}$ values, which was measured by the total RNA $(0.2-200 \mathrm{ng})$. The slope and y-intercept were then calculated. Each amount of mRNA was calculated according to the formula:

$$
\text { mRNA amount (ng as total RNA) }=10^{(\mathrm{CT}-\mathrm{b}) / \mathrm{m}}
$$

where $b$ is the $y$-intercept of the standard curve line and $m$ is the slope of the standard curve line.

Finally, the 5HT2A receptor mRNA expressions were normalized to GAPDH mRNA.

\section{Monitoring of Hindlimb Blood Perfusion}

Hindlimb blood perfusion was scanned by using a laser Doppler perfusion image (LDPI) analyzer (Moor Instruments, Devon, UK) on the first day of treatment and then every 7 days until the end of the study period. To eliminate the influence of the surgical procedure, the average blood perfusion of the bilateral feet was evaluated. To minimize influential variables including ambient light and temperature, perfusion was expressed as the ratio of the blood perfusion in the right (ischemic) limb to that in the left (nonischemic) limb of the same mouse, that is, in terms of the LDPI index (LDPII) 17,25 Mice with a LDPII less than 0.2 on the first day of the experiment were defined as having hindlimb ischemia. 


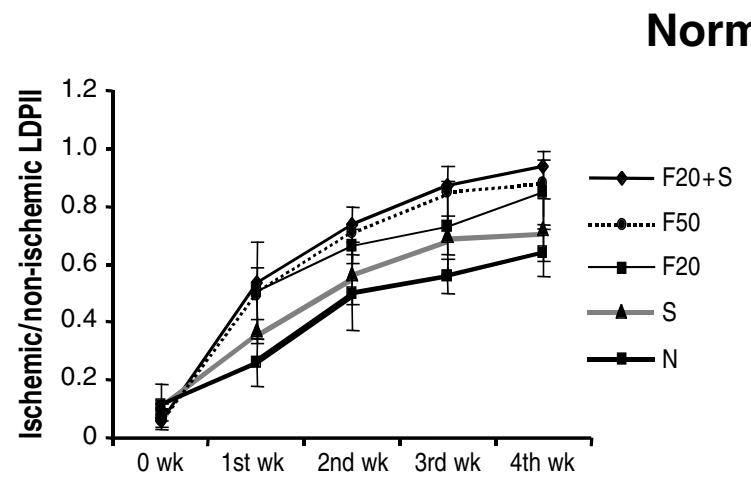

Time after initiation of treatment

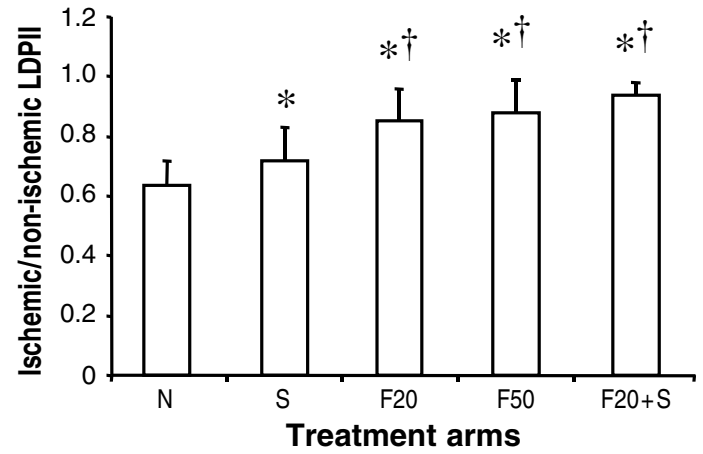

\section{DM}
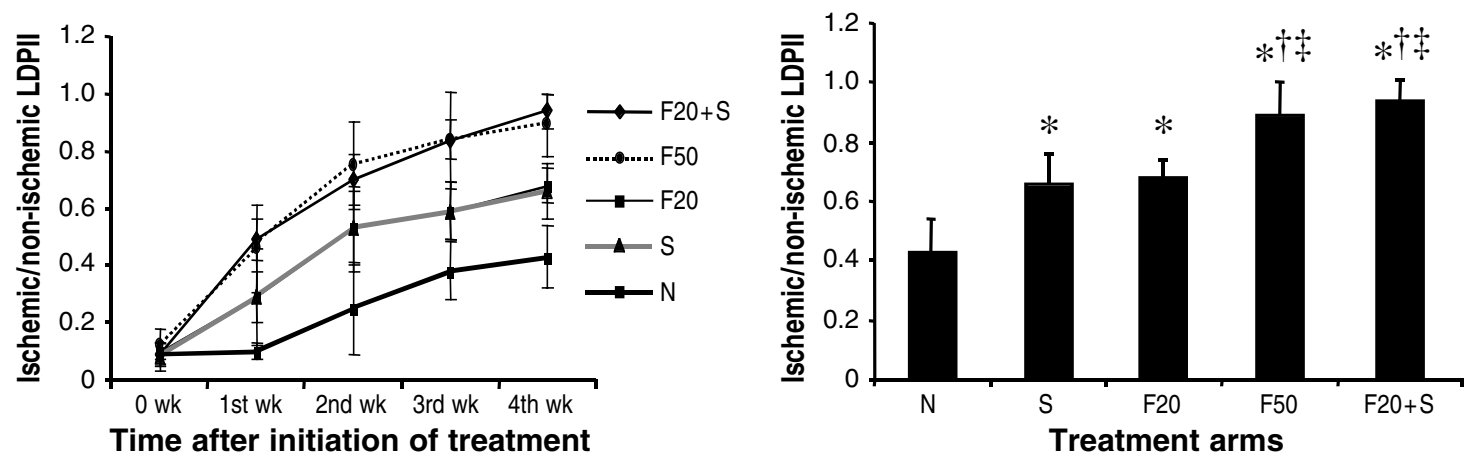

Fig 2. Left panels: Time-course of ischemic/non-ischemic blood perfusion ratio in normal and diabetic (DM) mice with various treatments. Right panels: ischemic/non-ischemic blood perfusion ratio in normal and DM mice at 4 weeks after various treatments. Group N, no treatment; group S, treatment with sarpogrelate; group F20, treatment with sustainedrelease $20 \mu \mathrm{g}$ basic fibroblast growth factor (bFGF); group F50, treatment with sustained-release 50 $\mathrm{g}$ bFGF; group $\mathrm{F} 20+\mathrm{S}$, combined treatment with sustained-release $20 \mu \mathrm{g}$ bFGF and sarpogrelate. ${ }^{*} \mathrm{p}<0.05$ vs group $\mathrm{N} ;{ }^{\dagger} \mathrm{p}<0.05$ vs group $\mathrm{S} ;{ }^{\star} \mathrm{p}<0.05$ vs group F20. LDPII, laser Doppler perfusion image index; wk, week.

\section{Immunohistological Analysis}

Four weeks after the initiation of treatment, the mice were euthanized and perfusion-fixed with $4 \%$ paraformaldehyde. The ischemic calf muscles were embedded in OCT compound (Sakura Finetechnical, Tokyo, Japan) and frozen at $-80^{\circ} \mathrm{C}$. Cryostat sections $(5 \mu \mathrm{m}$ thick) of the tissues were stained with rabbit polyclonal anti-human von Willebrand factor antibody (vWF; Dako Japan, Kyoto, Japan) or mouse monoclonal anti-human smooth muscle actin (SMA; SigmaAldrich Japan K.K., Tokyo, Japan) antibody. As the negative control, rabbit normal immunoglobulin fraction (Dako Japan, Kyoto, Japan) was used to show antibody specificity. From each mouse, 8 random fields on 2 different sections (approximately $3 \mathrm{~mm}$ apart) were photographed with a digital camera (Olympus, Tokyo, Japan). The numbers of vWF (endothelial marker)-positive, SMA (vascular smooth muscle marker)-positive vessels and muscle fibers were counted manually in a blind fashion. Vascular density (angiogenesis) was determined by the counted number of vWF-positive vessels and mature vessel density (arteriogenesis) was determined by the counted number of SMA positive vessels ${ }^{17}$

\section{Statistical Analysis}

Results are expressed as the mean $\pm \mathrm{SD}$. Differences among groups were determined by using one-way analysis of variance followed by multiple comparisons using the Bonferroni/Dunn's test. All statistical analyses were performed by using Statview ${ }^{\mathrm{TM}}$ software (Abacus, MI, USA). A $p$ value $<0.05$ was considered to be significant.

\section{Results}

Survival of Mice

One hundred of 112 mice survived 4 weeks after surgery. Thus, each treatment group of the normal and DM mice consisted of 10 mice.

\section{Blood Sugar Level and Body Weight Profile}

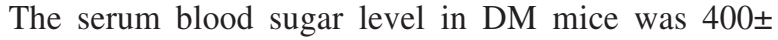
$109 \mathrm{mg} / \mathrm{dl}$, which was significantly higher than $146 \pm$ $22 \mathrm{mg} / \mathrm{dl}$ in normal mice $(\mathrm{p}<0.05)$. In contrast, the body weight of DM mice was significantly lower than that of normal mice $(23 \pm 1 \mathrm{~g}$ vs $25 \pm 1 \mathrm{~g}, \mathrm{p}<0.05)$.

\section{HT2A Receptor Expression}

The expression of 5HT2A receptors in the ischemic hindlimb was significantly higher than that in the non-ischemic hindlimb in both normal and DM mice at days 3 and 7 after surgery. The expression in the non-ischemic and the ischemic hindlimb in the DM mice were significantly higher than that in the non-ischemic and the ischemic hindlimb in normal mice, respectively (Fig 1).

\section{Hindlimb Blood Perfusion}

The time-course of LDPII in normal and DM mice are depicted in Fig 2; Left panels. In normal mice, the LDPII in groups S, F20, F50 and F20+S was significantly higher than that in the no-treatment group at 4 weeks after initiation of treatment $(0.63 \pm 0.08,0.72 \pm 0.11,0.85 \pm 0.11,0.88 \pm 0.11$ and 


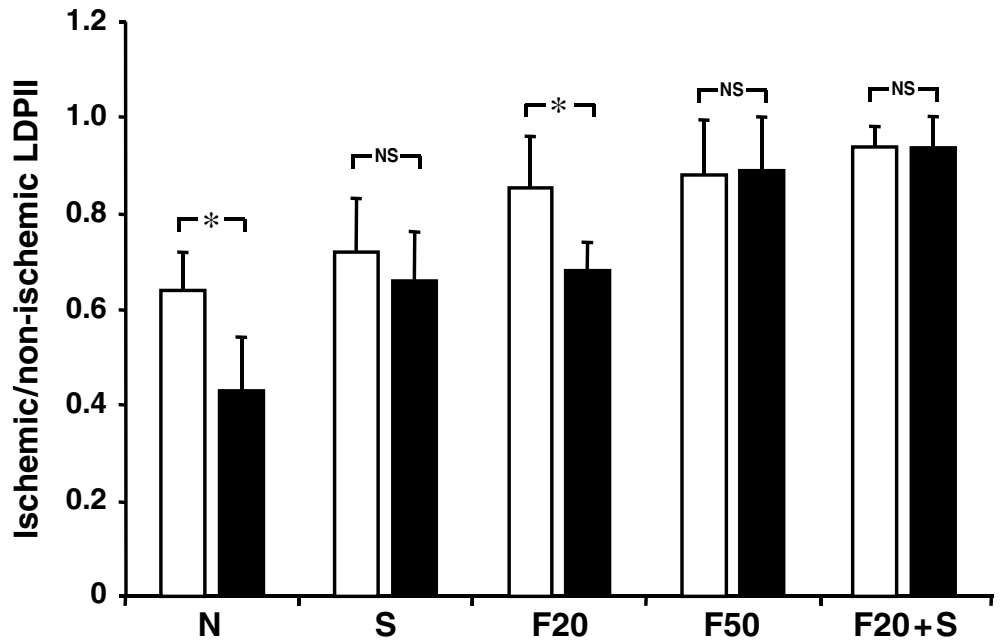

Fig 3. Comparison of the laser Doppler perfusion image index (LDPII) between normal (open bars) and diabetic (closed bars) mice at 4 weeks after various treatments. Group N, no treatment; group S, treatment with sarpogrelate; group F20, treatment with sustainedrelease $20 \mathrm{\mu} \mathrm{g}$ basic fibroblast growth factor (bFGF); group F50, treatment with sustained-release $50 \mathrm{\mu g}$ bFGF; group $\mathrm{F} 20+\mathrm{S}$, combined treatment with sustained-release $20 \mu \mathrm{g}$ bFGF and sarpogrelate; NS, not significant. ${ }^{*} \mathrm{p}<0.05$ vs normal mice.

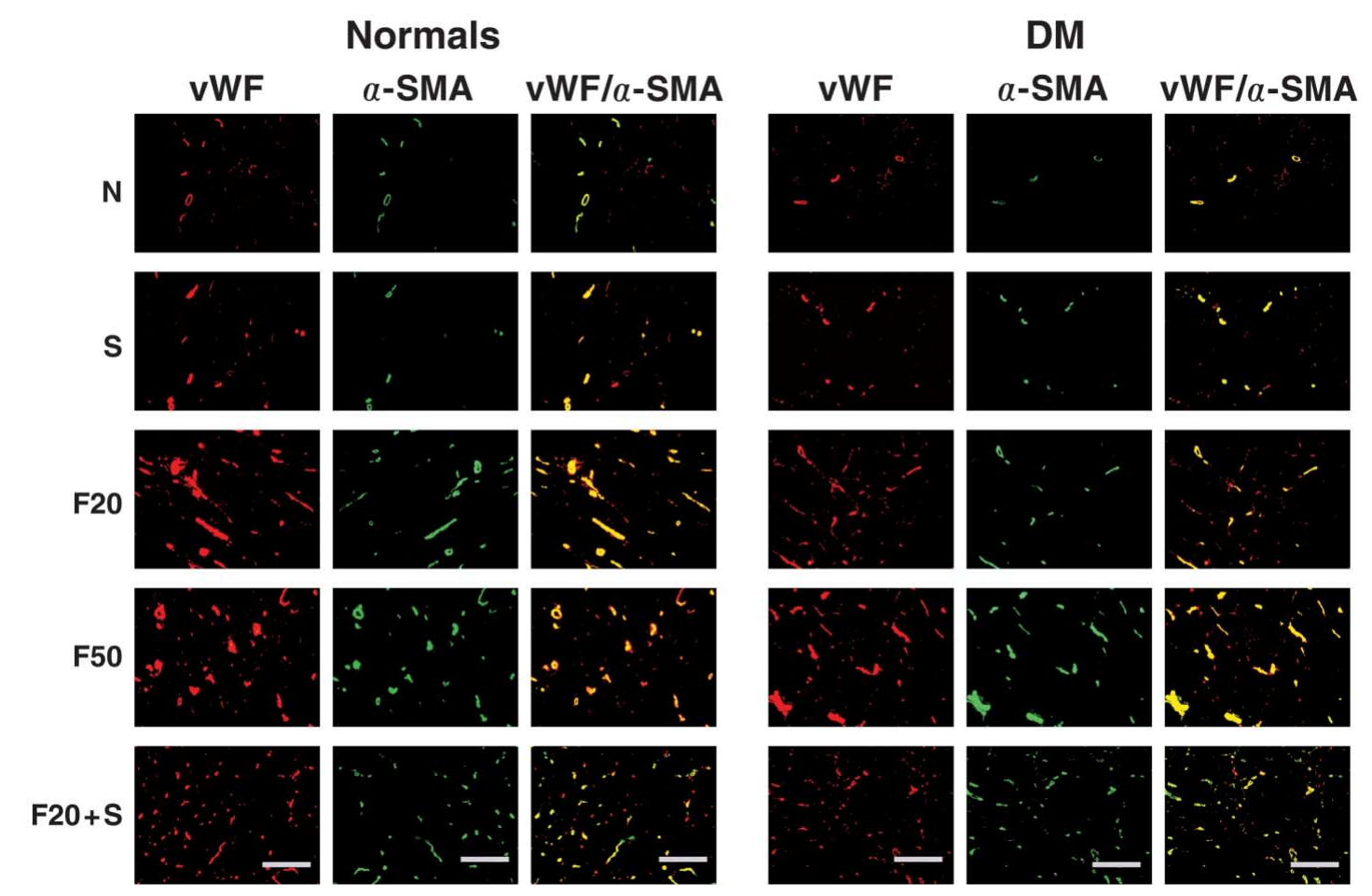

Fig 4. Representative photomicrographs of the ischemic calf muscles double stained with the anti-human von Willebrand factor antibody (vWF) and the anti-human smooth muscle actin (SMA) antibody at 4 weeks after surgery. Original magnification, $\times 200$; scale bars indicate $100 \mu \mathrm{m}$. Left panel: normal mice; right panel: diabetic $(\mathrm{DM})$ mice. Left column: vWF positive vessels; middle column: SMA positive vessels; right column: double-stained vessels. Group N, no treatment; group S, treatment with sarpogrelate; group F20, treatment with sustained-release $20 \mu \mathrm{g}$ basic fibroblast growth factor (bFGF); group F50, treatment with sustained-release 50 g bFGF; group F20+S, combined treatment with sustainedrelease $20 \mu \mathrm{g}$ bFGF and sarpogrelate.

$0.94 \pm 0.04$ for groups N, S, F20, F50, and F20+S, respectively; $\mathrm{p}<0.05)$. The LDPII in groups F20, F50 and F20+S was significantly higher than that in group S. No statistically significant difference in the LDPII was found in the F20, F50 and $\mathrm{F} 20+\mathrm{S}$ groups (Fig 2; Upper right panel). In DM mice, the LDPII in the S, F20, F50 and F20+S groups was significantly higher $(\mathrm{p}<0.05)$ than that in the no-treatment group at 4 weeks after initiation of treatment $(0.43 \pm 0.11$, $0.66 \pm 0.10,0.68 \pm 0.06,0.89 \pm 0.11$ and $0.94 \pm 0.06$ for groups $\mathrm{N}, \mathrm{S}, \mathrm{F} 20, \mathrm{~F} 50$ and F20+S, respectively). The LDPII in groups F50 and F20+S was significantly higher than that in
S and F20 groups. No statistically significant difference in terms of the LDPII was found between either the S and F20 groups or the between the $\mathrm{F} 50$ and $\mathrm{F} 20+\mathrm{S}$ groups (Fig 2; Lower right panel).

The LDPII in the no-treatment group in normal mice was significantly higher $(\mathrm{p}<0.05)$ than that in the no-treatment group in DM mice. The LDPII in normal mice with F20 treatment was also significantly higher $(\mathrm{p}<0.05)$ than that in DM mice with the same treatment. There was no statistically significant difference in the LDPII between normal and DM mice with S, F50 and F20+S treatments (Fig 3). 

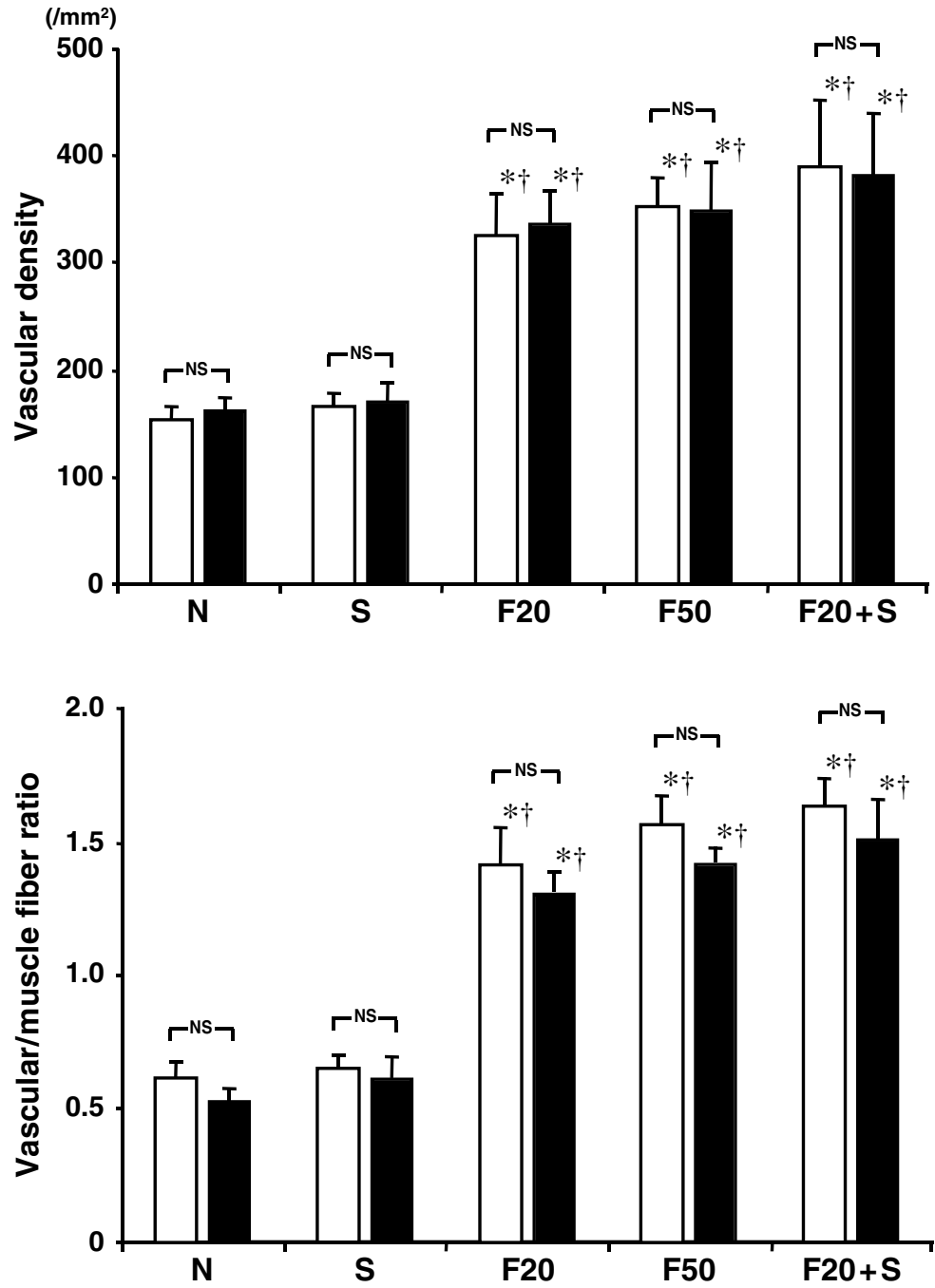

Fig 5. Comparison of the vascular density in the ischemic calf muscles between normal (open bars) and diabetic (closed bars) mice at 4 weeks after surgery. Group N, no treatment; group S, treatment with sarpogrelate; group F20, treatment with sustained-release $20 \mu \mathrm{g}$ basic fibroblast growth factor (bFGF); group F50, treatment with sustained-release $50 \mu \mathrm{g}$ bFGF; group F20+S, combined treatment with sustained-release $20 \mathrm{ug}$ bFGF and sarpogrelate; NS, not significant. $* \mathrm{p}<0.05$ vs group $\mathrm{N} ;{ }^{\dagger} \mathrm{p}<0.05 \mathrm{vs}$ group $\mathrm{S}$.
Fig 6. Comparison of the vascular/muscle fiber ratio in the ischemic calf muscles between normal (open bars) and diabetic (closed bars) mice at 4 weeks after surgery. Group N, no treatment; group S, treatment with sarpogrelate; group F20, treatment with sustained-release $20 \mu \mathrm{g}$ basic fibroblast growth factor (bFGF); group F50, treatment with sustained-release $50 \mu \mathrm{g}$ bFGF; group $\mathrm{F} 20+\mathrm{S}$, combined treatment with sustained-release $20 \mathrm{\mu g}$ bFGF and sarpogrelate; NS, not significant. ${ }^{*} \mathrm{p}<0.05$ vs group $\mathrm{N} ;{ }^{\dagger} \mathrm{p}<0.05$ vs group $\mathrm{S}$.
The percent increase in the LDPII for DM mice treated with sarpogrelate was a mean $54 \%$, which is higher than the $14 \%$ mean in normal mice.

\section{Vascular Density}

Representative photomicrographs of histological sections in the normal and DM mice are shown in Fig 4. In normal mice, the vascular density in the groups F20, F50, and F20+S was significantly higher than that in the other 2 groups $\left(154 \pm 12,166 \pm 13,326 \pm 39,352 \pm 27\right.$ and $390 \pm 64$ vessels $/ \mathrm{mm}^{2}$ for groups N, S, F20, F50 and F20+S, respectively; p<0.05). There was no statistically significant difference in the vascular density between groups $\mathrm{N}$ and $\mathrm{S}$. No statistically significant difference in the vascular density was found among the groups F20, F50, and F20+S (Fig 5). In DM mice, the vascular density in the groups F20, F50 and F20+S was significantly higher than that in the other 2 groups $(161 \pm 14$, $170 \pm 18,336 \pm 31,348 \pm 46$ and $381 \pm 58$ vessels $/ \mathrm{mm}^{2}$ for groups $\mathrm{N}, \mathrm{S}, \mathrm{F} 20, \mathrm{~F} 50$ and $\mathrm{F} 20+\mathrm{S}$, respectively; $\mathrm{p}<0.05$ ). There was no statistically significant difference in the vascular density between the groups $\mathrm{N}$ and $\mathrm{S}$. No statistically significant difference in the vascular density was found among groups F20, F50, and F20+S (Fig 5).

The vascular density in the no-treatment group in normal mice was comparable with that in the no-treatment group in DM mice. There was no statistically significant difference in the vascular density between normal and DM mice with each treatment (Fig 5). The percentage increase in the vascular density with sarpogrelate treatment in DM mice was $6 \%$ in mean, which is comparable with $8 \%$ in mean in normal mice.

\section{Vascular/Muscle Fiber Ratio}

The vascular/muscle fiber ratios in normal and DM mice are shown in Fig 6. In normal mice, the vascular/muscle fiber ratio was $0.62 \pm 0.05,0.65 \pm 0.05,1.42 \pm 0.13,1.56 \pm 0.12$ and $1.63 \pm 0.10$ vessels/muscle fiber for groups N, S, F20, F50 and F $20+S$, respectively. In DM mice, it was $0.52 \pm 0.05,0.61 \pm$ $0.08,1.31 \pm 0.08,1.42 \pm 0.06$ and $1.51 \pm 0.15$ vessels/muscle fiber for groups N, S, F20, F50 and F20+S, respectively. All data in the vascular/muscle fiber ratio were directionally similar to those in the vascular density.

\section{Mature Vessel Density}

Representative photomicrographs of histological sections in normal and DM mice are shown in Fig 4. In normal mice, the mature vessel density in groups S, F20, F50 and F20+S was significantly higher than that in the no-treatment group $\left(12 \pm 4,21 \pm 3,45 \pm 15,45 \pm 8\right.$ and $51 \pm 14$ vessels $/ \mathrm{mm}^{2}$ for groups N, S, F20, F50 and F20+S, respectively; p $<0.05$ ). The mature vessel density in groups F20, F50 and F20+S was also significantly higher than that in group $\mathrm{S}$, but no 


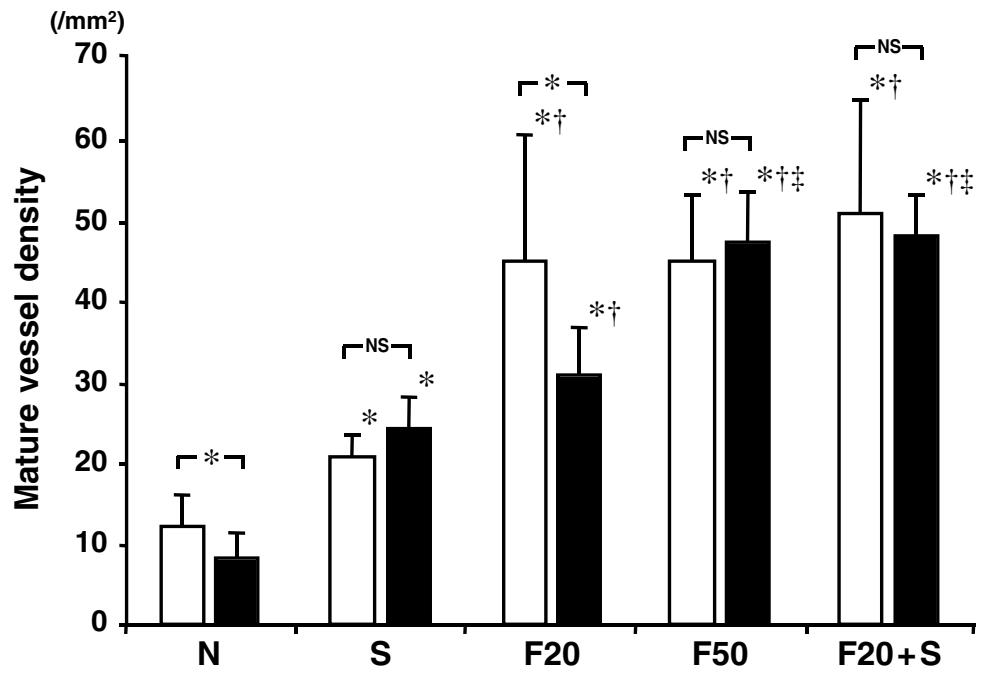

Fig 7. Comparison of the mature vessel density in the ischemic calf muscles between normal (open bars) and diabetic (closed bars) mice at 4 weeks after surgery. Group N, no treatment; group S, treatment with sarpogrelate; group F20, treatment with sustained-release $20 \mu \mathrm{g}$ basic fibroblast growth factor (bFGF); group F50, treatment with sustained-release $50 \mu \mathrm{g}$ bFGF; group F20+S, combined treatment with sustained-release $20 \mu \mathrm{g}$ bFGF and sarpogrelate; NS, not significant. $* \mathrm{p}<0.05$ vs normal mice; ${ }^{*} \mathrm{p}<0.05$ vs group $\mathrm{N} ;{ }^{\dagger} \mathrm{p}<0.05$ vs group $\mathrm{S}$; ${ }^{\mathrm{p}}<0.05$ vs group F20. statistically significant difference was found among groups F20, F50 and F20+S (Fig 7). In DM mice, the mature vessel density in groups $\mathrm{S}, \mathrm{F} 20, \mathrm{~F} 50$ and $\mathrm{F} 20+\mathrm{S}$ was significantly higher than that in the no-treatment group $(8 \pm 3,24 \pm 4,31 \pm$ $5,47 \pm 6$ and $48 \pm 5$ vessels $/ \mathrm{mm}^{2}$ for groups $\mathrm{N}, \mathrm{S}, \mathrm{F} 20, \mathrm{~F} 50$ and $\mathrm{F} 20+\mathrm{S}$, respectively; $\mathrm{p}<0.05$ ). The mature vessel density in groups F20, F50 and F20+S was significantly higher than that in group $\mathrm{S}$. The mature vessel density in groups $\mathrm{F} 50$ and $\mathrm{F} 20+\mathrm{S}$ was also significantly higher than that in group F20. No statistically significant difference in the mature vessel density was found between groups F50 and F20+S (Fig 7).

The mature vessel density in the no-treatment group in normal mice was significantly higher $(\mathrm{p}<0.05)$ than that in the no-treatment group in DM mice. The mature vessel density in normal mice with F20 treatment was significantly higher $(\mathrm{p}<0.05)$ than that in DM mice receiving the same treatment (Fig 7). The percentage increase in the mature vessel density with sarpogrelate treatment in DM mice was $200 \%$ in mean, which was higher than $75 \%$ in mean in normal mice.

\section{Discussion}

The new findings in this study are as follows: (1) sarpogrelate treatment for hindlimb ischemia was more effective in DM mice compared with normal mice; (2) the treatment with sustained-release bFGF was also effective in DM mice, which needed a higher dose of bFGF or a combined treatment of bFGF and sarpogrelate.

Neovascularization is categorized into angiogenesis, arteriogenesis and vasculogenesis. In the present study, we focused on the 2 former components. Angiogenesis represents the process of endothelial cell replication and migration leading to formation of capillary networks, while arteriogenesis is the maturation and enlargement of size of the pre-existing small vessels through vascular remodeling?26,27 Some investigators have demonstrated that arteriogenesis is defective and angiogenesis is enhanced or unaffected in DM!1,12,28-30 The present study showed that angiogenesis (capillary spouting) was unaffected, although arteriogenesis and blood flow were impaired in DM mice. The aim was to restore blood flow as a result of enhanced arteriogenesis, which supports the concept that the clinical impact of collateral arteries is based on their ability to proliferate into large conductance arteries (arteriogenesis), which can very efficiently restore blood flow to the ischemic territories 31,32

Arteriogenesis plays a crucial role in collateral growth.6,31 Therapeutic angiogenesis with various growth factors has been extensively investigated over the last several years. Among angiogenic growth factors, bFGF is known to be one of the most potent stimulators of arteriogenesis $27,33,34$ The process of arteriogenesis involves a variety of vessel wall cells including endothelial cells, smooth muscle cells and fibroblasts, and bFGF has broad potential to act as a growth factor for these cells 33 Additionally, bFGF does not only promote proliferation of endothelial cells but it also induces the development of a medial layer and adventitia, which could sustain and support the endothelium from the outside 35 To achieve the optimal collateral circulation, a choice of growth factors and their delivery system are the most important factors. Because the half-life of bFGF in its free form is very short, we used controlled and sustainedrelease bFGF incorporated in gelatin hydrogel microspheres! $17,18,22$

In the present study, beneficial effects of sarpogrelate on ischemic hindlimb perfusion was exaggerated in the DM mice, presumably due to blockade of severe constriction of native collateral vessels as a result of increased expression of $5 \mathrm{HT}_{2} \mathrm{~A}$ receptors. Our findings on the enhanced expression of $5 \mathrm{HT}_{2} \mathrm{~A}$ receptors in DM mice were in agreement with those previously reported by Janiak et al. ${ }^{21}$ It is tempting to speculate on the mechanism of augmented arteriogenesis with sarpogrelate treatment. The increased collateral blood flow mediated by sarpogrelate, a blockade of the $5 \mathrm{HT}_{2} \mathrm{~A}$ receptor, possibly augments shear stress at the site of pre-existent collateral vessels. Arteriogenesis is potentiated by the amplification of endogenous endothelial signaling mediated by changes in shear stress ${ }^{36-38}$ Our findings are in agreement with earlier reports, which demonstrated that a serotonin blocker effectively improved the distal perfusion in hindlimb ischemia in the fatty zucker rat. ${ }^{21}$ While sarpogrelate has been reported to be effective for rabbits with hindlimb ischemia ${ }^{22}$ and anginal patients, 39,40 more favorable effects of sarpogrelate are expected to be observed in patients with PAD and effort angina complicated by DM.

In this current study, we utilized GAPDH to normalize the $5 \mathrm{HT}_{2} \mathrm{~A}$ receptor expression based on results from an earlier study ${ }^{1}$ However, in a diabetic condition, GAPDH 
expression might be suppressed by reactive oxygen species production.1 ${ }^{4}$ Therefore, this means that the use of other genes such as $\beta$-actin or 18s rRNA might be better for mRNA normalization42,43 During this study, a conventional fluorescence light microscope was used, which was, to some extent, unable to distinguish endothelial and smooth muscle cell layers conspicuously but did confirm the overlapping or collocated cells. In order to distinguish double labeling in the case of 2 distinct collocated cells from a single one in the same tissue section, a confocal microscope instead of conventional microscope is required 44,45

Collectively, the results of the present study showed that angiogenesis is preserved but regional blood flow and arteriogenesis are impaired in hindlimb ischemia of STZinduced DM mice. Although $20 \mu \mathrm{g}$ bFGF was sufficient to induce therapeutic angiogenesis in hindlimb ischemia of normal mice, a higher dose of bFGF $(50 \mu \mathrm{g})$ was required for the same effect in DM mice. Furthermore, a combined treatment with sustained-release $20 \mu \mathrm{g}$ bFGF and sarpogrelate showed the same outcome as the treatment with $50 \mu \mathrm{g}$ bFGF. Thus, in DM mice, an intrinsic response to the stimuli for arteriogenesis was impaired, but the treatment effect of sustained-release bFGF was well preserved. These results might be applicable in the clinical setting in patients with PAD complicated by DM. Further investigations are certainly needed to fully define the mechanisms of the detrimental effect of DM on vascular disease using new and more sophisticated approaches.

\section{Acknowledgments}

The authors would like to thank Mrs Fumiyo Kataoka, Miss Yukiko Okumura, Miss Mari Ishii, Miss Maiko Yamamoto (Kyoto University Graduate School of Medicine), and also Miss Yu Takeuchi (Suzuka University of Medical Science) for their kind experimental assistance. This work was partially supported by Mitsubishi Pharma Co, Japan. The part of this study was presented at the 2006 Scientific Sessions of the American Heart Association.

\section{References}

1. Stamler J, Vaccsro O, Neaton JD, Wentworth D. Diabetes, other risk factors, and 12 year cardiovascular mortality for men screened in the multiple risk factor, interventional trial. Diabetes Care 1993; 16: 434-444.

2. Smith JW, Marcus FI, Serokman R. Prognosis of patients with diabetes mellitus after acute myocardial infarction. Am J Cardiol 1984; 54: $718-721$

3. Abbott RD, Donahue RP, Kannel WB, Wilson PF. The impact of diabetes on survival following myocardial infarction in men versus women: The Framingham study. JAMA 1988; 260: 3456-3460.

4. European Working Group on Critical Leg Ischemia. Second European consensus document on chronic critical leg ischemia. Circulation 1991; 84(Suppl): IV-1 - IV-26.

5. Isner JM, Pieczek A, Schainfeld R, Blair R, Haley L, Asahara T, et al. Clinical evidence of angiogenesis after arterial gene transfer of $\mathrm{ph}$ VEGF 165 in patient with ischemic limb. Lancet 1996; 348: 370374.

6. Rajagopalan S, Mohler ER, Lederman RJ, Mendelsohn FO, Saucedo JF, Goldman CK, et al. Regional angiogenesis with vascular endothelial growth factor in peripheral arterial disease: A phase II randomized double blind control study of adenoviral delivery of VEGF 121 in patients with disabling intermittent claudication. Circulation 2003; 108: $1933-1938$

7. Carmeliet P. VEGF gene therapy: Stimulating angiogenesis or angioma-genesis? Nat Med 2000; 6: 1102-1103.

8. Ferrara N, Alitalo K. Clinical applications of angiogenic growth factors and their inhibitors. Nat Med 1999; 5: 1359-1364.

9. Yancopoulos GD, Davis S, Gale NW, Rudge JS, Wiegand SJ, Holash J. Vascular specific growth factors and blood vessel formation. Nature 2000; 407: 242-248.

10. Feener EP, King GL. Vascular dysfunction in diabetes. Lancet 1997; 350(Suppl): I-9-I-13.
11. Abaci A, Oguzhan A, Kahraman S, Eryol NK, Unal S, Arinc H, et al. Effects of diabetes on formation of coronary collateral vessels. Circulation 1999; 99: 2239-2242.

12. Waltenberger J. Impaired collateral vessels development in diabetes: Potential cellular mechanism and therapeutic implications. Cardiovasc Res 2001; 49: 554-560.

13. Ferrara N, Gerber HP. Role of vascular endothelial growth factor in angiogenesis. Acta Haematol 2001; 106: 148-156.

14. D'Amore PA, Smith SR. Growth factor effects on cell of the vascular wall; a survey. Growth Factors 1993; 8: 61-67.

15. Bikfalvi A, Klein S, Pintucci G, Rifkin DB. Biological roles of fibroblast growth factor-2. Endcr Rev 1997; 18: 26-45.

16. Hosaka A, Koyama H, Kushibiki T, Tabata Y, Nishiyama N, Miyata $\mathrm{T}$, et al. Gelatin hydrogel microspheres enable pinpoint delivery of basic fibroblast growth factor for the development of functional collaterals. Circulation 2004; 110: 3322-3328.

17. Marui A, Kanematsu A, Yamahara K, Doi K, Kushibiki T, Yamamoto $\mathrm{M}$, et al. Simultaneous application of basic FGF and HGF to enhance the blood vessel formation. J Vasc Surg 2005; 41: 82-90.

18. Iwakura A, Tabata Y, Koyama T, Doi K, Nishimura K, Kataoka K, et al. Gelatin sheet incorporating basic FGF to enhances sternal healing after harvesting bilateral internal thoracic arteries. J Thorac Cardiovasc Surg 2003; 126: $1113-1120$.

19. Molyszko J, Urano T, Knofler R, Taminato A, Yoshimi T, Takada Y, et al. Daily variations of platelets aggregation in relation to blood and plasma serotonin in diabetes. Thromb Res 1994; 75: 569-576.

20. Loots W, De Clerck F. 5-Hydroxytryptamine dominates over thromboxane $\mathrm{A}_{2}$ in reducing collateral blood flow by activated platelets. Am J Physiol Heart Circ Physiol 1993; 34: H158-H164.

21. Janiak P, Lainee P, Grataloup Y, Luyt C, Bidouard J, Michel J, et al. Serotonin receptor blockade improves distal perfusion after lower limb ischemia in the fatty zucker rat. Cardiovasc Res 2002; 56: 293 302.

22. Hirose K, Fujita M, Marui A, Arai Y, Sakaguchi H, Huang Y, et al. Combined treatment of sustained-release basic fibroblast growth factor and sarpogrelate enhances collateral blood flow effectively in rabbit hindlimb ischemia. Circ J 2006; 70: 1190-1194.

23. Hara H, Osakabe M, Kitajima A, Tamao Y, Kikumoto R. MCI-9042, a new antiplatelet agent is a selective $\mathrm{S}_{2}$ serotonergic receptor antagonist. Thromb Haemost 1991; 65: 415-420.

24. Rees DA, Alcolado JC. Animal models of diabetes mellitus. Diabetic Med 2004; 22: 359-370.

25. Couffinhal T, Silver M, Zheng LP, Kearney M, Witzenbichler B, Isner JM. Mouse model of angiogenesis. Am J Pathol 1998; 152: $1667-1679$.

26. Carmeliet P. Mechanisms of angiogenesis and arteriogenesis. Nat Med 2000; 6: 389-395.

27. van Royen N, Piek JJ, Buchmann I, Hoefer I, Voskuil M, Schaper W. Stimulation of arteriogenesis; a new concept for the treatment of arterial occlusive disease. Cardivasc Res 2001; 49: 543-553.

28. Simons M. Angiogenesis: Where do we stand now? Circulation 2005; 111: $1556-1566$.

29. Weihrauch D, Lohr NL, Mraovic B, Ludwig LM, Chilian WM, Pagel PS, et al. Chronic hyperglycemia attenuates coronary collateral development and impairs proliferative properties of myocardial interstitial fluid by production of angiostatin. Circulation 2004; 109: $2343-$ 2348.

30. van Weel V, de Vries M, Voshol PJ, Verloop RE, Eilers PHC, van Hinsbergh VWM, et al. Hypercholesterolemia reduces collateral artery growth more dominantly than hyperglycemia or insulin resistance in mice. Arterioscler Thromb Vasc Biol 2006; 26: 1383-1390.

31. Fujita M, Tambara K. Recent insights into human coronary collateral development. Heart 2004; 90: 246-250.

32. Bushmann I, Schaper W. The pathophysiology of collateral circulation (arteriogenesis). J Pathol 2000; 190: 338-342.

33. Baffour R, Berman J, Garb JL, Rhee SW, Kaufman J, Friedmann P. Enhanced angiogenesis and growth of collaterals by in vivo administration of recombinant basic fibroblast growth factor in a rabbit model of acute lower limb ischemia: Dose-response effect of basic fibroblast growth factor. J Vasc Surg 1992; 16: 181-191.

34. Tomanek RJ, Sanrda A, Zheng W, Brock T, Bjercke RJ, Holifield JS. Vascular endothelial growth factor and basic fibroblast growth factor differentially modulate early postnatal coronary angiogenesis. Circ Res 2001; 88: $1135-1141$.

35. Klagsburn M. The fibroblast growth factor family: Structural and biological properties. Prog Growth Factor Res 1989; 1: 207-235.

36. Helisch A, Schaper W. Arteriogenesis: The development and growth of collateral arteries. Microcirculation 2003; 10: 83-97.

37. Kersten JR, Pagel PS, Chilian WM, Warltier DC. Multifactorial basis for coronary collateralization; a complex adaptive response to 
ischemia. Cardiovasc Res 1999; 43: 44-57.

38. Wahlberg E. Angiogenesis and arteriogenesis in limb ischemia. $J$ Vasc Surg 2003; 38: 198-203.

39. Kinugawa T, Fujita M, Lee JD, Nakajima H, Hanada H, Miyamoto S. Effectiveness of a novel serotonin blocker, sarpogrelate, for patients with angina pectoris. Am Heart J 2002; 144: E1.

40. Tanaka T, Fujita M, Nakae I, Tamaki S, Hasegawa K, Kihara Y, et al. Improvement of exercise capacity by sarpogrelate as a result of augmented collateral circulation in patients with effort angina. J Am Coll Cardiol 1998; 32: 1982-1986.

41. Wentzel P, Ejdesjo A, Eriksson UJ. Maternal diabetes in vivo and high glucose in vitro diminish GAPDH activity in rat embryos. Diabetes 2003; 52: $1222-1228$

42. Biederman J, Yee J, Cortes P. Validation of internal control genes for gene expression analysis in diabetic glomerulosclerosis. Kidney International 2004; 66: 2308-2314.

43. Catalan V, Gomez-Ambrosi J, Rotellar F, Silva C, Rodriguez A, Salvador J, et al. Validation of endogenous control genes in human adipose tissue: Relevance to obesity and obesity-associated type 2 diabetes mellitus. Horm Metab Res 2007; 39: 495-500.

44. Rajantie I, Ilmonen M, Alminaite A, Ozerdem U, Alitalo K, Salven P. Adult bone marrow-derived cells recruited during angiogenesis comprise precursors for periendothelial vascular mural cells. Blood 2004; 104: $2084-2086$.

45. Lu H, Xu X, Zhang M, Cao R, Bråkenhielm E, Li C, et al. Combinatorial protein therapy of angiogenic and arteriogenic factors remarkably improves collaterogenesis and cardiac function in pigs. Proc Natl Acad Sci USA 2007; 104: 12140-12145. 